INTER NATIONAL BULLETIN OF BACTER IOLOGICAL
NOMENCLATURE AND TAXONOMY
$\begin{array}{llll}\text { Volume } 9 & \text { No. } 3 & \text { July } 15,1959 & \text { pp. } 133-136\end{array}$

\title{
ON THE PAST AND PRESENT NOMENCLATURE OF CERTAIN BACTERIA
}

\author{
W. J. Dowson \\ Botany School \\ University of Cambridge
}

The following essay is a plea for the consideration of giving descriptive names to any newly recorded bacteria in preference to the modern practice of using names of people, places or even any word. All three are permissible under the present rules of nomenclature.

In the early days of microbiology most of the names given to those "animalcules" we now call bacteria had a definite meaning and were in fact a brief description of the microorganisms concerned. They were moreover derived from Latin or Greek words.

Rule 5 of the International Bacteriological Code of Nomenclature (5) permits the creation from any source whatever of both generic and species (trivial) names for bacteria, no matter if the name or word proposed means anything or is a mere sound. Usually such names are manufactured from those of persons or places and are in no sense descriptive. Unlike the older names, many modern ones convey no information at all about the nature of the bacterium concerned.

For those unacquainted with Latin or Greek, reference to a classical dictionary will explain the meaning of the words derived from the ancient languages and will tell them at once something about the organism. This is not so with the words derived from the names of persons or places. No dictionary defines Escherichia or Klebsiella and a student may well wonder what sort of an organism Klebsiella is. To be informed that this mysterious sound is the name of a genus of bacteria and was given by Trevisan in honour of the late Professor Klebs only adds to the enquirer's bewilderment. It does not tell him what he really wants to know which is something about the organism, 1.e. is it rod-shaped, spherical or spiral or has it any prominent character such as gas-formation?

The following examples are cited to emphasize the above remarks. Some of the original names are still in use and are valid. Thus, in 1773 Muller named a motile, comma- 
shaped microbe Vibrio which is derived from the Latin vibro, I vibrate or tremble. The name of the cholera pathogen given by Bergey (2) is $\mathrm{V}$. comma (Schroeter) Winslow et al., a descriptive name signifying the vibrating commashaped organism. Similarly Ehrenberg in 1830 coined the name Spirillum from the Greek speira, a coil, and $\underline{S}$. undula (Muller) Ehrenberg describes two characteristics of one species and means the wave-like coiled microbe. In 1872 Cohn called the common hay organism Bacillus subtilis which is derived from the Latin bacillum, a little rod, and subtilis, slender. The name is again descriptive and means the slender little rod. Escherich in 1885 named the common bacterium of the colon Bacterium coli commune partly from the Greek bakterion, a little rod, and partly from Latin. The meaning of the name is quite obvious - the little rod common in the colon. In 1897 Chester called a frequently occurring, gas-forming micro-organism Bacterium aerogenes from the Greek aer, air or gas, and genao, I generate. The name describes two characters of the organism and means the gas-generating little rod.

An older name which however was not descriptive was that of the micro-organism responsible for the apparently miraculous blood-red colouring of carbohydrate-containing substances such as maize meal. It was named Serratia marcescens in 1823 by Bizio in honour of the Italian physicist Serrati. The trivial name is Latin, marcescens, meaning withering away or dissolving, so that the name Serratia marcescens signifies the withering away or dissolving Serrati. Many other generic names have been used for this organism and a further trivial name, prodigiosa, was given by Ehrenberg in 1849, meaning miraculous. Topley and Wilson (7) used the very sensible and descriptive combination Chromobacterium prodigiosum (from the Greek chroma, colour,) i.e. the miraculous coloured small rod. Bergey (2) reverts to the original one given by Bizio, on grounds of priority, because the starting date for bacteriological nomenclature is considered to be Linnaeus, Species Plantarum, Ed. 1, 1 May 1753. However, as Ainsworth and Cowan (1) state, "many bacteriologists think that the starting date should be much later, and certainly in the era of pure cultures".

In recent years the older names have been superseded by words derived from the names of eminent deceased men 
of science, not always bacteriologists. Thus in $1919 \mathrm{Cas-}$ tellani and Chalmers proposed the name Escherichia coli in honour of Escherich who first described and named the colon bacterium Bacterium coli commune. Escherichia coli means the Escherichia of the colon. But what is an Escherichia and how is it pronounced?

Beijerinck in 1900 proposed the name Aerobacter aerogenes, almost a tautonym, for the former Bacterium aerogenes; but this is surpassed by the most recent proposal, again on the grounds of priority, to call this organism Klebsiella aerogenes (the genus Klebsiella was created by Trevisan in 1885 in honour of Klebs) and the name means literally the gas-generating little Klebs!

Apart from these inappropriate names Ainsworth and Cowan (1) admit a taxonomic difficulty in that Klebsiella and Aerobacter can seldom be separated so that " $\overline{\mathrm{B}}$ " aerogenes may have two generic names according to the interpretation of all its characters as determined by eachinvestigator.

In view of the above considerations the author suggests that the establishment of an appropriate new generic name may not only solve some of these nomenclatural and taxonomic problems but $w$ ill also provide a substitute for the generic name Bacterium, in which the author (3) placed the coliform bacterial plant pathogens and some other similar bacteria. Bacterium is now invalid, International Bulletin of Bacteriological Nomenclature and Taxonomy, (6) and at present the se coliform plant pathogens may be considered as either species of the genus Erwinia Winslow et al. (9) or Pectobacterium Waldee (8). The first is not descriptive as it is derived from a person's Christian name but the second can be applied to those coliforms possessing pectic enzymes, such as the soft rot bacteria of the plant pathogens, and for these it is a very suitable generic name (Dowson, 4).

The possible objection that there is not enough variety in bacterial morphology or physiology from which to coin descriptive names of all bacteria may be met by the undoubted fact that there are far too many genera based on only one or two characters which could be combined. The various species would be distinguished by trivial names e.g. the specific epithets fluorescens and berberidis distinguish two species of the genus Pseudomonas and the one generic name 
conveys the further information that both species possess some characters in common. (fluorescens = producing fluorescence and berberidis = of the barberry; Pseudomonas, Greek pseudes false and Monas a genus of infusoria $=$ the false Monas).

It is perhaps significant that the specific epithets of bacteria do not in general change and in the laboratory a bacterium is recognized by its species name without reference to its genus the name of which may be subject to change. The name "coli", for instance, is usually understood to refer to one group of very similar organisms no matter whether the generic name has been changed from Bacterium to Escherichia. Similarly the name "aerogenes" alone is generally sufficient to identify the bacterium whose generic name has been subjected to more than one alteration, i.e. from Bacterium to Aerobacter and now to Klebsiella.

\section{REFERENCES}

I. Ainsworth, G.C. and S.T. Cowan. (1954). J. Gen, Microbiol. 10:465.

2. Bergey, D.H. et al. (1948). Manual of Determinative Bncteriology. Williams and Wilkins Co., Baltimore.

3. Dowson, W.J. (1949). Manual of Bacterial Plant Diseases. A. and C. Black, Lend.

4. (1957). Diseases of Plants due to Bacteria. Camb. Univ. Press.

5. International Bacteriological Code of Nomenclature. (1947) in J. Bact. 1948. 55:287 and J. Gen. Microbiol. 1949. 3:444.

6. International Bulletin of Bacteriological Nomenclature and Taxonomy. (1953). 3(4):159.

7. Topley, W.C. and G.S. Wilson. (1931). Principles of Bacteriology and Immunity. Arnold, London. lst ed. p. 402 .

8. Waldee, E.L. (1945). Iowa State Coll. J. Sci. 19:435.

9. Winslow, C.E.A. et al. (1917). J. Bact. 2:560. 